\title{
Combined Immunoaffinity cDNA-RNA Hybridization Assay for Detection of Hepatitis A Virus in Clinical Specimens
}

\author{
ROBERT W. JANSEN, ${ }^{1}$ JOHN E. NEWBOLD, ${ }^{2}$ AND STANLEY M. LEMON ${ }^{1,2 *}$ \\ Division of Infectious Diseases, Department of Medicine, ${ }^{1 *}$ and Department of Microbiology and Immunology, ${ }^{2}$ \\ University of North Carolina at Chapel Hill, Chapel Hill, North Carolina 27514
}

Received 12 June 1985/Accepted 20 August 1985

\begin{abstract}
To apply cDNA-RNA hybridization methods to the detection of hepatitis A virus (HAV) in clinical materials, we developed a two-step method in which a microtiter-based, solid-phase immunoadsorption procedure incorporating a monoclonal anti-HAV capture antibody was followed by direct blotting of virus eluates to nitrocellulose and hybridization with ${ }^{32}$ P-labeled recombinant HAV cDNA. This immunoaffinity hybridization method is simple and involves few sample manipulations, yet it retains high sensitivity (10- to 30-fold more than radioimmunoassay) and is capable of detecting approximately $1 \times 10^{5}$ to $2 \times 10^{5}$ genome copies of virus. The inclusion of the immunoaffinity step removes most contaminating proteins and thus facilitates subsequent immobilization of the virus for hybridization. It also permits positive hybridization signals to be related to specific antigens and adds a level of specificity to the hybridization procedure. When the method was applied to 23 fecal specimens collected from individuals during week 1 of symptoms due to hepatitis $\mathrm{A}, 13$ specimens were found to be reproducibly positive for HAV RNA by immunoaffinity hybridization, whereas only 11 contained viral antigen detectable by radioimmunoassay.
\end{abstract}

Wild-type hepatitis A virus (HAV) grows only poorly in cell culture, and primary isolation of the virus is slow and unpredictable $(3,20)$. Other methods, such as immune electron microscopy (8) or solid-phase immunoassays (22), have therefore been used for the detection of HAV in clinical specimens or in specimens collected from experimentally infected nonhuman primates. Compared with these older immunologically based methods for detection of the virus, the recent application of cDNA-RNA hybridization by using ${ }^{32} \mathrm{P}$-labeled recombinant cDNA probes appears to offer enhanced sensitivity (21). However, this potential advantage may be offset by the presence in crude fecal suspensions of contaminating nucleic acids or proteins that may result in false-positive hybridization signals $(1,5)$. Even the use of highly purified cDNA insert probes may not totally overcome this limitation, which is not restricted to the HAV system (1). In addition, the preparation of RNA contained in clinical specimens for hybridization may involve several steps, including denaturation and protease digestion of proteins followed by chemical extraction of viral RNA (21), and thus often entails multiple manipulations of each specimen. This makes the procedure difficult to apply to many samples and is an additional factor hindering the application of hybridization techniques to clinical materials.

We avoided the problems inherent in cDNA-RNA hybridization of grossly contaminated clinical specimens, such as fecal suspensions, by the incorporation of a simple solidphase immunoadsorption procedure before the immobilization of viral RNA on nitrocellulose paper. The technical simplicity of this procedure is further enhanced by the fact that HAV, when suspended in a medium with low protein content, may be blotted directly onto nitrocellulose paper, without prior protease digestion or extraction with organic solvents, and subsequently is detected by cDNA-RNA hybridization without loss of sensitivity. In this paper, we describe this combined immunoaffinity hybridization ap-

\footnotetext{
* Corresponding author.
}

proach to the detection of HAV and its application to human fecal specimens.

\section{MATERIALS AND METHODS}

HAV. Cell culture-adapted HAV was purified from infected BS-C-1 cell culture supernatant fluids by polyethylene glycol precipitation and repetitive isopycnic and rate-zonal ultracentrifugation, as described previously (14).

Antibody. Monoclonal antibody to HAV was the generous gift of A. G. Coulepis and I. D. Gust, Fairfield Hospital, Melbourne, Australia (17). Monoclonal antibody to mycoplasma attachment protein was obtained from P.-C. $\mathrm{Hu}$, University of North Carolina School of Medicine, Chapel Hill, and was used as a specificity control.

Clinical material. Fecal samples were obtained from New World owl monkeys (11) and human volunteers (4) undergoing experimental infection with $\mathrm{HAV}$, as well as from individuals involved in natural outbreaks of hepatitis A occurring in Kansas and the Federal Republic of Germany (10). Fecal specimens were tested as 10 to $20 \%$ suspensions made in normal saline or Hanks balanced salt solution and clarified at 7,000 $\times g$ for $30 \mathrm{~min}$.

RNA extractions. Total cellular RNA was extracted from normal and HAV-infected BS-C-1 cells by the guanidinium thiocyanate-cesium chloride method (18). Virion RNA was obtained by treatment of gradient-purified HAV with proteinase $\mathrm{K}$ and sodium dodecyl sulfate (SDS), followed by phenol-chloroform extraction and ethanol precipitation (25). For the extraction of RNA from fecal suspensions, samples were subjected to $1 \%$ SDS and proteinase $\mathbf{K}$ digestion for 30 min at $37^{\circ} \mathrm{C}$, followed by extraction with phenol-chloroform and subsequent blotting to nitrocellulose.

Solid-phase immunoaffinity purification of HAV for hybridization. Individual wells of polyvinyl chloride " $U$ " bottom microtiter plates (Dynatech Laboratories, Inc., Alexandria, Va.) were coated with $100 \mu$ l of murine ascitic fluid (K3-2F2) containing monoclonal antibody to HAV (17) diluted $1: 1,000$ in $50 \mathrm{mM}$ sodium carbonate buffer $(\mathrm{pH} 9.6)$. After $4 \mathrm{~h}$ of incubation at $37^{\circ} \mathrm{C}, 100 \mu \mathrm{l}$ of $1 \%$ bovine serum albumin, also 
diluted in carbonate buffer, was added to each well, and the microtiter plates were incubated for an additional hour at $37^{\circ} \mathrm{C}$. The microtiter wells were then washed twice with phosphate-buffered saline containing $0.05 \%$ Tween 80 and loaded with samples (50 to $100 \mu \mathrm{l})$ of tissue culture fluids, gradient fractions, or fecal suspensions containing HAV. After an overnight incubation at $4^{\circ} \mathrm{C}$, the wells were washed three times with phosphate-buffered saline, and the virus bound to the solid-phase support was eluted by the addition of $100 \mu$ l of $0.1 \mathrm{~N} \mathrm{HCl}$. After $30 \mathrm{~min}$ at room temperature, the eluate was aspirated from the wells and applied directly to nitrocellulose for hybridization as described below.

Blotting of HAV to nitrocellulose paper. RNA extracts were diluted with 3 volumes of $10 \times \operatorname{SSC}(1 \times \mathrm{SSC}$ is $0.15 \mathrm{M}$ $\mathrm{NaCl}$ plus $0.015 \mathrm{M}$ sodium citrate) in $6.15 \mathrm{M}$ formaldehyde (G. Wahl, "Sequences" application update 371, Schleicher \& Schuell, Inc., Keene, N.H.) and were heated before being blotted for $15 \mathrm{~min}$ at $65^{\circ} \mathrm{C}$. For blotting of whole-virus samples, specimens were diluted into either $500 \mu \mathrm{l}$ of $7.5 \times$ SSC in $4.6 \mathrm{M}$ formaldehyde (blotting buffer, for samples of $50 \mu \mathrm{l}$ or less) or 3 volumes of $10 \times$ SSC in $6.15 \mathrm{M}$ formaldehyde (for all other whole-virus samples, including $\mathrm{HCl}$-released immunoaffinity eluates). Blotting consisted of direct application to BA85 nitrocellulose paper (Schleicher \& Schuell) in the Minifold II slot blotter (Schleicher \& Schuell), followed by one wash with $10 \times$ SSC. After air drying for at least $30 \mathrm{~min}$, the nitrocellulose papers were baked at $80^{\circ} \mathrm{C}$ in a vacuum oven for at least $2 \mathrm{~h}$.

HAV cDNA probes. Escherichia coli cultures containing recombinant $\mathrm{pBR} 322$ plasmids $\mathrm{pHAV}_{\mathrm{LB}} 1307$, $\mathrm{pHAV}_{\mathrm{LB}} 148$, and $\mathrm{pHAV}_{\mathrm{LB}} 228$ which contain inserts of cDNA complementary to portions of wild-type (6th marmoset passage) HM-175 strain virion RNA were obtained from J. R. Ticehurst of the National Institute of Allergy and Infectious Diseases, Bethesda, Md. (25). After large-scale culture growth and plasmid amplification by standard procedures (18), plasmid DNA was isolated from lysed $E$. coli cultures by repetitive banding in $\mathrm{CsCl}$-ethidium bromide gradients. HAV cDNA inserts were excised from plasmid DNA by digestion with PstI, electrophoretically separated from pBR322 DNA in a low-melting-point agarose gel (Bethesda Research Laboratories, Inc., Gaithersburg, Md.), and recovered as previously described (7). Three different probes were used for most of the described work. These included probe 1307-2 (approximately 700 bases long, derived from the $5^{\prime}$ end of the HAV genome, and extending approximately 44 bases into the putative VP2 coding sequence), probe 1307-1 (approximately 1,900 bases long, starting 152 bases $3^{\prime}$ of probe 1307-2 and spanning most of the putative capsid sequence region), and probe 228 (approximately 2,200 bases long and spanning the central portion of the genome) $(2,25)$. ${ }^{32}$ P-labeled probes were prepared from purified insert DNA by partial denaturation followed by random priming with calf thymus oligodeoxynucleotide fragments and $E$. coli DNA polymerase I (24). Labeled DNA was precipitated with ethanol, dissolved in water, and used directly in the hybridization assay described below.

cDNA-RNA hybridization. Nitrocellulose papers were prehybridized for at least $3 \mathrm{~h}$ at $42^{\circ} \mathrm{C}$ in a solution containing $50 \%$ formamide (MCB Manufacturing Chemists Inc., Darmstadt, Federal Republic of Germany), $2.5 \times$ Denhardt solution, $5 \times \mathrm{SSC}, 0.1 \% \mathrm{SDS}$, and denatured calf thymus DNA at $100 \mu \mathrm{g} / \mathrm{ml}$. For hybridization, the prehybridization solution was replaced with a similar solution containing only $1 \times$ Denhardt solution and ${ }^{32} \mathrm{P}$-labeled probe at a concentration of $0.5 \times 10^{6}$ to $2.5 \times 10^{6} \mathrm{cpm} / \mathrm{ml}$. The probe was boiled for $3 \mathrm{~min}$ immediately before dilution into hybridization solutions. Hybridization was performed at $42^{\circ} \mathrm{C}$ in the presence of $50 \%$ formamide with gentle shaking for at least $22 \mathrm{~h}$. The nitrocellulose was washed twice with $2 \times$ SSC $-0.1 \%$ SDS at room temperature for 15 to $30 \mathrm{~min}$ per wash and twice with $0.1 \times \mathrm{SSC}-0.1 \% \mathrm{SDS}$ at $52^{\circ} \mathrm{C}$ for 20 to $30 \mathrm{~min}$ per wash. After brief blotting on Whatman 3MM filter paper, the nitrocellulose papers were sealed in plastic wrap and placed in film cassettes containing Kodak XAR-5 film (Eastman Kodak Co., Rochester, N.Y.) and Kodak X-Omatic intensifying screens. The films were developed after exposure for $16 \mathrm{~h}$ to 8 days at $-70^{\circ} \mathrm{C}$. The intensity of hybridization signals was assessed by laser densitometry with an LKB Ultroscan (LKB Instruments, Turku, Finland).

Solid-phase radioimmunoassay for HAV. HAV antigen was detected in fecal suspensions and gradient fractions by a solid-phase radioimmunoassay described previously (15). A positive result was defined in this assay by a speci$\mathrm{men} /$ control cpm ratio of 2.1 or greater and was considered specific for $\mathrm{HAV}$ in fecal specimens only if positive results were competitively blocked $50 \%$ or more after the addition of convalescent chimpanzee serum to the radiolabeled detector antibody. When noted, monoclonal anti-HAV murine ascitic fluid (17), diluted $1: 1,000$ in carbonate buffer, replaced the polyclonal capture antibody normally used in this assay.

\section{RESULTS}

cDNA-RNA hybridization after direct blotting of intact HAV. In an attempt to bypass protease and detergent treatments and phenol-chloroform extractions for the preparation of HAV RNA, we blotted suspensions of purified virions directly onto nitrocellulose. Purified virion suspensions (14) (either untreated or treated with various combinations of proteinase $\mathrm{K}$ digestion and SDS denaturation), diluted into $7.5 \times \mathrm{SSC}-4.6 \mathrm{M}$ formaldehyde blotting buffer and applied directly to nitrocellulose, gave a positive hybridization signal. The intensity of this signal was not enhanced by prior treatment of the virus with either proteinase $\mathrm{K}$ or SDS (data not shown). To compare the sensitivity of direct blotting of virus with blotting of RNA prepared by a proteinase K-SDS-phenol-chloroform extraction procedure (25), both methods were applied to a series of dilutions made from sucrose gradient-purified virus (Fig. 1, lanes $A$ and $C$ ) and a positive human fecal specimen (Fig. 1, lanes D and F). In several different experiments, direct blotting of virus proved 3 to 30 times more sensitive than blotting of extracted RNA in terms of the highest sample dilution yielding a positive hybridization signal. The lower ratio, 3, was obtained when $1 \mathrm{mM}$ aurintricarboxylic acid, a potent RNase inhibitor, was included in the RNA extraction mixture. Incubation of whole-virus blots with RNase after the baking of the nitrocellulose paper but before the prehybridization step eliminated the positive hybridization signal, indicating that immobilized ${ }^{32} \mathrm{P}$ was due to cDNA-RNA hybridization and not to nonspecific binding or trapping of probe by viral or other proteins (data not shown). By quantitatively comparing blot intensities obtained when probe 1307-2 was hybridized in the same experiment against a known quantity of purified plasmid pHAV $\mathrm{LB}_{\mathrm{LB}} 113$ DNA (containing sequences identical to those in the probe) (25), the minimal quantity of virus detectable with the direct blot method was estimated to be 1 $\times 10^{5}$ to $2 \times 10^{5} \mathrm{HAV}$ genome copies, or less than $5 \times 10^{3}$ radioimmunofocus-forming units of virus (12).

Immunoaffinity hybridization. Whereas direct blotting provides a simple and efficient means of detecting $\mathrm{HAV}$ in cell 


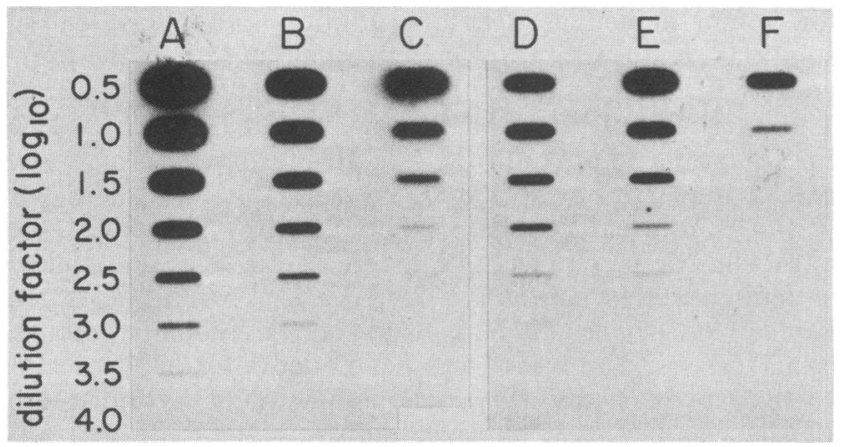

FIG. 1. Comparison of different methods for the detection of HAV RNA in a gradient-purified, cell culture-adapted virus preparation (lanes $A$ to $C$ ) and a representative virus-positive fecal specimen (GR8 [Tables 2 and 3]; lanes D to F). Indicated dilutions were prepared for both samples and then subjected to direct blotting (lanes A and D), immunoaffinity hybridization (lanes B and E), or RNA extraction followed by RNA blotting (lanes $C$ and F). The probe was 1307-1; autoradiographs were exposed for $72 \mathrm{~h}$. Undiluted gradient-purified virus was estimated to contain $4 \times 10^{9}$ genome copies per $\mathrm{ml}$, and the $20 \%$ GR8 fecal suspension contained about $4 \times 10^{8}$ genome copies per $\mathrm{ml}$ (based on a comparison with purified plasmid DNA).

culture supernatant fluids and gradient fractions, its application to the detection of viral RNA in fecal suspensions is not practical. In concentrated fecal suspensions (20\%), contaminating proteins and other debris frequently clog the pores of the nitrocellulose paper to such a degree that sample flow is substantially impeded (see below). Moreover, the binding of probe to extraneous proteins and nucleic acids (possibly including common DNA vector sequences) may lead to false-positive hybridization signals $(1,5)$. These problems were eliminated by the introduction of a simple solid-phase immunoaffinity purification step which removed contaminating materials before blotting. The wells of plastic microtiter plates were coated with monoclonal antibody to HAV (17) at a dilution that was determined to be optimal, and the resulting solid-phase immunoadsorbent was used to bind the virus present in clinical specimens. (In preliminary experiments with a solid-phase radioimmunoassay, we had confirmed that this monoclonal antibody [K3-2F2] was broadly reactive against several $\mathrm{HAV}$ strains and capable of efficiently binding the HM-175, PA-21, GR-8, LV-374, and MS-1 strains of the virus.)

Several different elution buffers or denaturing solutions were assessed for their ability to remove virus bound to the antibody-coated solid phase (Table 1). The efficiency of each elution buffer was assessed by direct blotting of the eluate (diluted 10-fold in blotting buffer) to nitrocellulose, followed by hybridization with the HAV cDNA probe, and by reacting the residual virus remaining bound to the solid-phase with ${ }^{125}$ I-anti-HAV (13). The strongest hybridization signals were achieved when virus was eluted with $1 \%$ SDS or $0.1 \mathrm{~N}$ $\mathrm{HCl}$, although $0.1 \mathrm{~N} \mathrm{HCl}$ resulted in more complete removal of virus from the solid phase. Blot intensities achieved after immunoaffinity purification of the virus and elution with $1 \%$ SDS or $0.1 \mathrm{~N} \mathrm{HCl}$ were somewhat greater than those achieved with direct blotting of the virus suspension, and this may reflect the removal of $0.1 \%$ bovine serum albumin present in the original virus diluent. Because $0.1 \mathrm{~N} \mathrm{HCl}$ resulted in more consistent hybridization signals than the use of $1 \% \mathrm{SDS}, 0.1 \mathrm{~N} \mathrm{HCl}$ was used in subsequent experiments. However, preliminary results suggested that $1 \%$ SDS might
TABLE 1. Efficiency of various buffers in eluting HAV in the solid-phase immunoadsorption procedure

\begin{tabular}{lcc}
\hline $\begin{array}{c}\text { Elution } \\
\text { buffer }\end{array}$ & $\begin{array}{c}\text { Blot intensity } \\
(\%)^{a}\end{array}$ & $\begin{array}{c}\text { Residual bound } \\
\text { antigen (cpm) } \\
(\%)^{b}\end{array}$ \\
\hline $5 \% \mathrm{TCA}^{c}$ & $0(0)$ & $112(3)$ \\
$1 \mathrm{~N} \mathrm{HCl}$ & $0(0)$ & $72(2)$ \\
$0.1 \mathrm{~N} \mathrm{HCl}$ & $1,147(145)$ & $202(5)$ \\
$4 \mathrm{M} \mathrm{Urea}$ & $410(52)$ & $2,201(54)$ \\
$0.5 \mathrm{M} \mathrm{Urea}$ & $27(3)$ & $3,196(79)$ \\
$4 \mathrm{M} \mathrm{GTC}$ & $228(29)$ & $122(3)$ \\
$1 \%$ SDS & $1,439(182)$ & $2,091(51)$ \\
\hline
\end{tabular}

a cDNA-RNA hybridization signal intensity measured by laser densitometry (percent of blot intensity obtained with direct blotting of the same virus sample). In each case, virus was $50 \mu \mathrm{l}$ of gradient-purified HAV suspended in $0.1 \%$ bovine serum albumin; direct blotting of this material gave a blot intensity of 787 . The probe was whole plasmid $\mathrm{pHAV}_{\mathrm{LB}} 148$ (25).

${ }^{b}$ Residual HAV antigen bound to the solid-phase support after the elution of virus detected with ${ }^{125} \mathrm{I}$-anti-HAV (percent of total virus sample counts per minute $[4,066 \mathrm{cpm}])$.

c TCA, Trichloroacetic acid.

${ }^{d}$ GTC, Guanidinium thiocyanate.

be a reasonable alternative for use with other, acid-sensitive picornaviruses.

The sensitivity of the combined immunoaffinity hybridization prodedure was compared with that of direct blotting of virus present in dilutions made from both gradient-purified virus (Fig. 1, lanes A and B) and a positive human fecal suspension (Fig. 1, lanes D and E). These two procedures gave comparable results in terms of the highest dilutions at which viral RNA could be detected, although hybridization signal intensities were somewhat greater with the direct blotting method at the highest dilutions. In terms of virus titer determined by endpoint dilution, both hybridization procedures were 10 - to 30 -fold more sensitive than a conventional solid-phase radioimmunoassay (15) or a similar assay incorporating a monoclonal antibody (K3-2F2) for antigen capture (Table 2). The difference between the immunoassay and hybridization methods was less impressive with the crude fecal suspension than with gradient purified virus, possibly owing to the presence of viral antigen that was not associated with RNA in the fecal specimen.

Despite the fact that comparable endpoint titers were obtained when the direct blotting and immunoaffinity hybridization methods were applied to the specimens shown in Fig. 1 , there was a substantial difference in the blot intensities at

TABLE 2. Sensitivity of direct blot, immunoaffinity hybridization, and solid-phase immunoassays for detection of $\mathrm{HAV}$

\begin{tabular}{|c|c|c|}
\hline \multirow[b]{2}{*}{ Method } & \multicolumn{2}{|c|}{$\log _{10}$ endpoint titer with: } \\
\hline & $\begin{array}{l}\text { Purified } \\
\text { HAV }^{a}\end{array}$ & $\begin{array}{c}\text { Fecal } \\
\text { specimen } \\
\text { GR8 }^{a}\end{array}$ \\
\hline Immunoaffinity hybridization $^{b}$ & $>4.0$ & 3.5 \\
\hline Direct blot, hybridization & $>4.0$ & 3.5 \\
\hline RNA blot, hybridization & 3.0 & 2.0 \\
\hline Solid-phase radioimmunoassay & & \\
\hline Monoclonal capture antibody & 3.0 & 3.0 \\
\hline Polyclonal capture antibody & 2.5 & 3.0 \\
\hline
\end{tabular}

${ }^{a}$ Purified HAV was estimated to contain $4 \times 10^{9}$ genome copies per ml, whereas fecal specimen GR8 contained about $4 \times 10^{8}$ genome copies per ml.

${ }^{b}$ The probe was 1307-1; autoradiograph exposure time was $72 \mathrm{~h}$. 


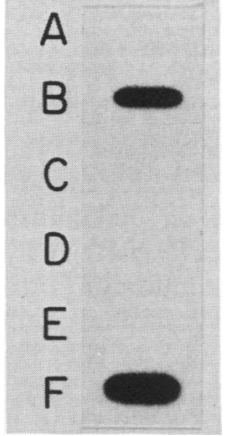

FIG. 2. Specificity of the cDNA probe and the immunoaffinity hybridization procedure for HAV. Slots A and B represent DNADNA hybridization in which DNA from $2 \times 10^{7} E$. coli cells was immobilized on nitrocellulose and hybridized with the HAV insert probe. (A) E. coli containing plasmid pBR322. (B) E. coli containing the related plasmid pHAV ${ }_{\mathrm{LB}} 1307$ (25). Slots $\mathrm{C}$ to $\mathrm{E}$ represent immunoaffinity hybridization blots of a normal, virus-negative fecal specimen spiked with $8 \times 10^{7}(\mathrm{C}), 4 \times 10^{8}(\mathrm{D})$, or $2 \times 10^{9}$ (E) CFU of $E$. coli containing $\mathrm{pHAV}_{\mathrm{LB}} 1307$ per $\mathrm{ml}$. Slot $\mathrm{F}$ is a direct blot of cell culture supernatant containing approximately $10^{4}$ radioimmunofocus-forming units of cell culture-adapted HAV (12). The probe was 1307-1; autoradiographs were exposed for $72 \mathrm{~h}$.

the lowest dilution of the fecal specimen. At this dilution, at which the concentration of fecal contaminants is maximal, significantly greater blot intensity was achieved with the immunoaffinity procedure than with direct blotting (Fig. 1, lanes $\mathrm{D}$ and $\mathrm{E} ; 0.5 \mathrm{log}$ dilution). This difference was not evident when the applied virus was first gradient purified (Fig. 1, lanes A and B). The reduced signal achieved with direct blotting of the concentrated fecal specimen was in part due to difficulties encountered in filtering it through the nitrocellulose but possibly was also related to contaminating proteins or nucleic acids or both interfering with the binding of filtered virus to the nitrocellulose. Together, these results suggest that the immunoaffinity hybridization procedure may be especially useful for fecal specimens containing amounts of virus that are too low to be detectable by direct blotting after the sample has been diluted to a point at which filtration may be efficiently accomplished.

Specificity of immunoafinity hybridization. An important advantage of the immunoaffinity hybridization procedure over direct blotting or more conventional approaches to the detection of virus by nucleic acid hybridization is the potential for enhanced specificity afforded by the monoclonal capture antibody. To assess the role played by the capture antibody in determining the specificity of the assay method, the monoclonal antibody coating the solid phase was replaced with an equal amount of murine monoclonal antibody directed against an unrelated antigen (mycoplasma) or carbonate buffer alone. Both modifications resulted in the complete elimination of the hybridization signal achieved with samples containing HAV (data not shown). To further assess specificity, a human fecal specimen that did not contain detectable HAV nucleic acid or antigen was spiked with a suspension of $E$. coli cells containing the plasmid $\mathrm{pHAV}_{\mathrm{LB}} 1307$ (pBR322 with a 2.8-kilobase HAV cDNA insert at the PstI site) (25). This mixture was subjected to immunoaffinity hybridization, using probe 1307-1 (Fig. 2, slots $C$ to $E$ ). As an additional control, a second sample of the fecal suspension was spiked with an equal amount of $E$. coli containing pBR322 (with no HAV insert) and tested in a similar fashion. In these experiments, the addition of $2 \times 10^{9}$
CFU of either bacterial strain per $\mathrm{ml}$ to the normal fecal suspension did not result in a positive hybridization signal, confirming a high degree of specificity conferred by the immunoaffinity step. When DNA was extracted from both strains of $E$. coli $\left(2 \times 10^{7} \mathrm{CFU}\right)$ and subjected to slot blotting and hybridization with the HAV probe, only DNA from the bacterial strain containing plasmid $\mathrm{pHAV}_{\mathrm{LB}} 1307$ evoked a positive hybridization response (Fig. 2, slots $A$ and $B$ ). This result indicated that the HAV cDNA probe had a high degree of specificity for HAV relative to pBR322 sequences. Thus, the overall immunoaffinity hybridization procedure had specificity conferred at two levels, the first being the monoclonal capture antibody and the second being the probe itself.

Detection of HAV RNA in human fecal specimens. Positive results were obtained with the immunoaffinity hybridization procedure when it was applied to known positive fecal specimens containing either strain MS-1 (4) or strain HM-175 (11) of the virus. In addition, virus was detected by this method in fecal specimens obtained from two recent outbreaks of hepatitis A, one of which occurred in North America and the other of which occurred in Europe (10). Thus, the combination of the monoclonal antibody and probe used in the procedure appears broadly reactive with a number of HAV strains. This is not surprising given the conditions of selection of the monoclonal antibody (17) and the degree of conservation apparent in the nucleotide sequence of several different HAV strains $(2,16,19)$.

Immunoaffinity hybridization was compared with the solid-phase radioimmunoassay for detection of HAV in fecal specimens collected during week 1 of illness from 23 men experiencing acute hepatitis A (10) (Table 3). Of these 23

TABLE 3. Comparison of immunoaffinity hybridization and solidphase radioimmunoassay for detection of HAV in human fecal samples

\begin{tabular}{|c|c|c|}
\hline Fecal specimen & $\begin{array}{l}\text { cDNA-RNA hybridization } \\
\text { blot intensity }{ }^{a}\end{array}$ & $\begin{array}{l}\text { Radioimmunoassay } \\
\text { P/N ratio }\end{array}$ \\
\hline \multicolumn{3}{|c|}{ Hybridization position } \\
\hline GR15 & 6,419 & 59.0 \\
\hline GR8 & 4,582 & 13.8 \\
\hline GR7 & 2,694 & 42.4 \\
\hline GR19 & 2,470 & 30.0 \\
\hline GR5 & 2,428 & 33.8 \\
\hline GR6 & 131 & 2.7 \\
\hline GR1 & 123 & 21.2 \\
\hline GR4 & 78 & 3.1 \\
\hline GR14 & 64 & 3.5 \\
\hline GR2 & 45 & $1.9(-)$ \\
\hline GR17 & 17 & 5.9 \\
\hline GR9 & 1 & 2.2 \\
\hline GR18 & 1 & $1.8(-)$ \\
\hline GR17 & $+1-c$ & $1.0(-)$ \\
\hline GR21 & $+1-$ & $2.0(-)$ \\
\hline \multicolumn{3}{|c|}{ Hybridization negative } \\
\hline GR3 & - & $1.4(-)$ \\
\hline GR10 & - & $1.1(-)$ \\
\hline GR11 & _ & $1.1(-)$ \\
\hline GR12 & - & $1.1(-)$ \\
\hline GR13 & - & $0.8(-)$ \\
\hline GR16 & - & $1.7(-)$ \\
\hline GR23 & - & $0.8(-)$ \\
\hline GR24 & - & $1.0(-)$ \\
\hline
\end{tabular}

${ }^{a}$ The probe was 228; autoradiograph exposure time was 8 days.

${ }^{b} \mathrm{P} / \mathrm{N}$ ratio, Positive/negative ratio.

$c+/-$, Not reproducibly positive on repeat testing. 
fecal specimens, 13 were reproducibly positive for HAV RNA by the hybridization method, whereas 2 others gave weakly positive results that were not confirmed on repeat testing. Two of the 13 reproducibly positive specimens and both of the questionably positive specimens were negative for HAV antigen by radioimmunoassay. Whereas the most intense hybridization signal was generally found with those specimens having the highest radioimmunoassay positive/negative values (highest antigen content), exceptions were noted in both directions (Table 3 ).

To confirm the specificity of the hybridization results, fecal specimens were tested by immunoaffinity hybridization by using both anti-HAV and an unrelated murine monoclonal antibody immobilized on the solid phase as capture antibodies; positive hybridization signals occurred only with the anti-HAV monoclonal antibody (Fig. 3).

For the sake of comparison, we attempted to directly blot the fecal suspensions. Substantial problems were encountered in accomplishing the filtration of sufficient quantities of these suspensions, owing to their high protein content. Although it was possible to subject $100 \mu$ l of each fecal suspension to testing by the immunoaffinity hybridization method, with 5 of the 23 specimens we were unable to completely filter $10 \mu \mathrm{l}$ of a $20 \%$ suspension (even after dilution in $200 \mu \mathrm{l}$ of blotting buffer). Five other specimens were successfully filtered only after an extended period, and only 6 of the 23 original specimens gave positive hybridization results with this approach (compared with 13 that were positive by immunoaffinity hybridization). Not surprisingly, these six positive specimens were those that were most strongly positive in the immunoaffinity hybridization assay (GR15, GR8, GR7, GR19, GR5, and GR6; Table 3). It is important to note that the greater sensitivity of the immunoaffinity hybridization method, when compared with the direct blotting of fecal specimens, may be largely related to

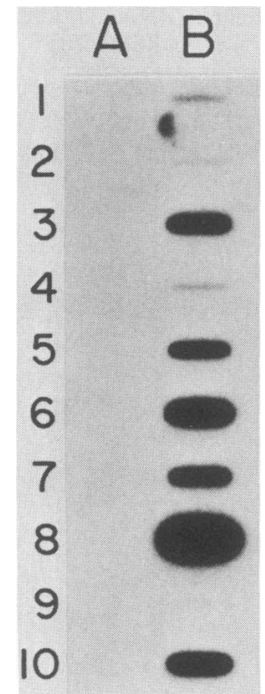

FIG. 3. Immunoaffinity hybridization of HAV present in suspensions of 10 human fecal specimens collected during week 1 of symptoms due to hepatitis A (10). Lane A, Blots of eluates from control microtiter plate wells coated with a murine monoclonal antibody to an unrelated, mycoplasmal antigen; lane B, blots of eluates from microtiter plate wells coated with the anti-HAV monoclone $\mathrm{K} 3-2 \mathrm{~F} 2$ (17). The probe was $1307-2$; autoradiographs were exposed for 8 days. the fact that the method makes possible the testing of a larger volume of the stool suspension.

\section{DISCUSSION}

The recent molecular cloning of the $\operatorname{HAV}$ genome $(16,19$, 25) provided important new reagents that now permit the detection of this virus in cell culture samples as well as clinical specimens by cDNA-RNA hybridization (21). However, the successful detection of viral nucleic acid by hybridization has previously entailed multiple manipulations of individual specimens, and we therefore sought to develop a simplified approach that would facilitate the application of cDNA-RNA hybridization to many specimens.

In comparing different methods for blotting HAV to nitrocellulose for subsequent detection by cDNA-RNA hybridization, we found that the direct application of virus suspended in a $7.5 \times \mathrm{SSC}-4.2 \mathrm{M}$ formaldehyde buffer resulted in a higher level of sensitivity than the blotting of RNA extracted from samples by a procedure involving SDS denaturation, proteinase $\mathrm{K}$ digestion, and extraction with organic solvents (Fig. 1). We suspect that under the conditions used for direct blotting, virions attached to the nitrocellulose are disrupted with the release of RNA onto the nitrocellulose during the baking of the paper. The greater sensitivity of the direct blotting method, compared with the blotting of chemically extracted RNA (Fig. 1), may be related either to the more efficient binding of virus to the nitrocellulose or to the physical loss or degradation of RNA during the extraction procedure. Regarding this latter possibility, preliminary experiments involving the extraction of RNA from virions that were intrinsically labeled with $\left[{ }^{3} \mathrm{H}\right]$ uridine have suggested that at least $50 \%$ of the virion RNA is recovered as acidprecipitable material. Previous investigators have noted the feasibility of directly blotting picornaviruses present in cell culture lysates to nylon membrane filters (23), and this may be a general attribute of this group of viruses. We used nitrocellulose exclusively for the experiments described in this paper. More recent experiments suggest that, whereas nylon filters such as Nytran (Schleicher \& Schuell) and Biodyne (ICN Biomedicals, Inc., Irvine, Calif.) may be substituted for nitrocellulose paper in the immunoaffinity hybridization procedure, they may be less efficient in binding intact virions.

Although we have found the direct blotting of virus to be extremely useful in monitoring the release of HAV into cell culture supernatant fluids or in tracking virus during purification procedures (14), it is not generally applicable to clinical specimens, owing to the frequent presence of large amounts of contaminating materials that interfere with the blotting process. We therefore developed a combined immunoaffinity hybridization method in an effort to arrive at a simple and practical yet sensitive method of applying cDNA hybridization to the detection of $\mathrm{HAV}$ in clinical materials. The new method offers significantly greater sensitivity than the conventional solid-phase radioimmunoassay for the detection of HAV in fecal specimens collected from acutely infected individuals (Tables 2 and 3). This added sensitivity was achieved with a minimum increase in the number of manipulations for each specimen. In addition, specificity problems that may be encountered in detecting viral nucleic acids in grossly contaminated specimens $(1,5)$ have been largely overcome by the combined use of highly purified insert probes and the incorporation of a simple solid-phase immunoaffinity purification step before the immobilization of the viral RNA. This additional step significantly enhances the specificity of the hybridization assay (without substan- 
tially reducing sensitivity) and permits positive hybridization signals to be related to specific antigens (Fig. 3). At the same time, the immunoaffinity step efficiently removes most contaminating proteins and results in the suspension of $\mathrm{HAV}$ particles in a medium that permits their direct blotting to nitrocellulose.

The specific immunoaffinity hybridization procedure we developed for the detection of HAV was intended for use in the research laboratory and is likely to prove useful in future studies of the pathogenesis of hepatitis $A$ in naturally infected humans or experimentally infected nonhuman primates. It is unlikely that any application in the clinical diagnostic laboratory will be found, as the diagnosis of acute hepatitis $\mathrm{A}$ is made more rapidly and with greater ease and sensitivity by the detection of virus-specific immunoglobulin $M$ antibodies $(6,13)$. Nonetheless, with appropriate modifications, the method described in this paper should prove generally applicable to other picornaviruses, including other enteroviruses. Antigenically distinct enteroviruses may share extensive nucleic acid homology, both at the 5 ' end of the genome in regions outside the open reading frame and within the 3 ' region of the genome which encodes the RNA polymerase $(2,9,23)$. This shared homology has been exploited by the successful use of poliovirus and coxsackievirus $B$ cDNA probes for the detection of antigenically unrelated enteroviruses in cell culture $(9,23)$. The inclusion of a simple immunoaffinity step, such as that described in this paper, before the immobilization of the virus for hybridization would provide a rapid means of establishing the immunologic identity of viruses detected with any of several different probes and could result in substantially improved methods for the detection of picornaviruses in clinical materials. Such an approach would permit the serotyping of enteroviruses and, potentially, the distinction of vaccine strain and wild-type polioviruses at a level of sensitivity offered only by cDNA hybridization.

\section{ACKNOWLEDGMENTS}

We are indebted to J. R. Ticehurst for providing $E$. coli strains bearing recombinant HAV plasmids and to A. G. Coulepis and I. D. Gust for the gift of murine monoclonal antibodies to HAV.

\section{LITERATURE CITED}

1. Barbacid, M. 1984. Bacterial contamination of human tumor samples. Science 225:670.

2. Baroudy, B. M., J. R. Ticehurst, T. A. Miele, J. V. Maizel, R. H. Purcell, and S. M. Feinstone. 1985. Sequence analysis of hepatitis A virus cDNA coding for capsid proteins and RNA polymerase. Proc. Natl. Acad. Sci. USA 82:2143-2147.

3. Binn, L. N., S. M. Lemon, R. H. Marchwicki, R. R. Redfield, N. L. Gates, and W. H. Bancroft. 1984. Primary isolation and serial passage of hepatitis A virus strains in primate cell cultures. J. Clin. Microbiol. 20:28-33.

4. Boggs, J. D., J. L. Melnick, M. E. Conrad, and B. F. Felsher. 1970. Viral hepatitis: clinical and tissue culture studies. J. Am. Med. Assoc. 214:1041-1046.

5. Dimitrov, D. H., D. Y. Graham, and M. K. Estes. 1985. Detection of rotaviruses by nucleic acid hybridization with cloned DNA of simian rotavirus SA11 genes. J. Infect. Dis. 152:293-300.

6. Duermeyer, W., F. Wielaard, and J. van der Veen. 1979. A new principle for the detection of specific IgM antibodies applied in an ELISA for hepatitis A. J. Med. Virol. 4:25-32.

7. Feinberg, A. P., and B. Vogelstein. 1984. A technique for radiolabelling DNA restriction endonuclease fragments to high specific activity. Anal. Biochem. 137:266-267.

8. Feinstone, S. M., A. Z. Kapikian, and R. H. Purcell. 1973. Hepatitis A: detection by immune electron microscopy of a virus-like antigen associated with acute illness. Science 182:1026-1028.

9. Hyypiä, T., P. Stålhandske, R. Vainionpää, and U. Pettersson. 1984. Detection of enteroviruses by spot hybridization. J. Clin. Microbiol. 19:436-438.

10. Lednar, W. M., S. M. Lemon, J. W. Kirkpatrick, R. R. Redfield, M. L. Fields, and P. W. Kelley. 1985. Frequency of illness associated with hepatitis A virus infection in adults. Am. J. Epidemiol. 122:226-233.

11. LeDuc, J. W., S. M. Lemon, C. M. Keenan, R. R. Graham, R. H. Marchwicki, and L. N. Binn. 1983. Experimental infection of the New World owl monkey (Aotus trivirgatus) with hepatitis A virus. Infect. Immun. 40:766-772.

12. Lemon, S. M., L. N. Binn, and R. H. Marchwicki. 1983. Radioimmunofocus assay for quantitation of hepatitis A virus in cell cultures. J. Clin. Microbiol. 17:834-839.

13. Lemon, S. M., C. D. Brown, D. S. Brooks, T. E. Simms, and W. H. Bancroft. 1980. Specific immunoglobulin $M$ response to hepatitis A virus determined by solid-phase radioimmunoassay. Infect. Immun. 28:927-936.

14. Lemon, S. M., R. W. Jansen, and J. E. Newbold. 1985. Infectious hepatitis A virus particles produced in cell culture consist of three distinct types with different buoyant densities in $\mathrm{CsCl}$. J. Virol. 54:78-85.

15. Lemon, S. M., J. W. LeDuc, L. N. Binn, A. Escajadillo, and K. G. Ishak. 1982. Transmission of hepatitis A virus among recently captured Panamanian owl monkeys. J. Med. Virol. 10:25-36.

16. Linemeyer, D. L., J. G. Menke, A. Martin-Gallardo, J. V. Hughes, A. Young, and S. W. Mitra. 1985. Molecular cloning and partial sequencing of hepatitis A viral cDNA. J. Virol. 54:247-255.

17. MacGregor, A., M. Kornitschuk, J. G. R. Hurrell, N. I. Lehmann, A. G. Coulepis, S. A. Locarnini, and I. D. Gust. 1983. Monoclonal antibodies against hepatitis A virus. J. Clin. Microbiol. 18:1237-1243.

18. Maniatis,T., E. F. Fritsch, and J. Sambrook. 1982. Molecular cloning: a laboratory manual. Cold Spring Harbor Laboratory, Cold Spring Harbor, N.Y.

19. Najarian, R., D. Caput, W. Gee, S. J. Potter, A. Renard, J. Merryweather, G. Van Nest, and D. Dina. 1985. Primary structure and gene organization of human hepatitis A virus. Proc. Natl. Acad. Sci. USA 82:2627-2631.

20. Provost, P. J., and M. R. Hilleman. 1979. Propagation of human hepatitis A virus in cell culture in vitro. Proc. Soc. Exp. Biol. Med. 160:213-221.

21. Purcell, R. H., S. M. Feinstone, J. R. Ticehurst, R. J. Daemer, and B. M. Baroudy. 1984. Hepatitis A virus, p. 9-22. In G. N. Vyas, T. L. Dienstag, and J. H. Hoofnagle (ed.), Viral hepatitis and liver disease. Grune \& Stratton, Inc., Orlando, Fla.

22. Purcell, R. H., D. C. Wong, Y. Moritsugu, J. L. Dienstag, J. Routenberg, and J. D. Boggs. 1976. A microtiter solid-phase radioimmunoassay for hepatitis $\mathrm{A}$ antigen and antibody. $\mathrm{J}$. Immunol. 116:349-356.

23. Rotbart, H. A., M. J. Levin, and L. P. Villarreal. 1984. Use of subgenomic poliovirus DNA hybridization probes to detect the major subgroups of enteroviruses. J. Clin. Microbiol. 20:1105-1108.

24. Summers, J. 1975. Physical map of polyoma viral DNA fragments produced by cleavage with a restriction enzyme from Haemophilus aegyptius, endonuclease R - HaeIII. J. Virol. 15:946-953.

25. Ticehurst, J. R., V. R. Racaniello, B. M. Baroudy, D. Baltimore, R. H. Purcell, and S. M. Feinstone. 1983. Molecular cloning and characterization of hepatitis A virus cDNA. Proc. Natl. Acad. Sci. USA 80:5885-5889. 